$1-1-1984$

\title{
A survey of the nutritional status of West Virginia peach orchards
}

Tara Lou Auxt

Suman Singha

Steve H. Blizzard

Follow this and additional works at: https://researchrepository.wvu.edu/ wv_agricultural_and_forestry_experiment_station_bulletins

\section{Digital Commons Citation}

Auxt, Tara Lou; Singha, Suman; and Blizzard, Steve H., "A survey of the nutritional status of West Virginia peach orchards" (1984). West Virginia Agricultural and Forestry Experiment Station Bulletins. 687.

https://researchrepository.wvu.edu/wv_agricultural_and_forestry_experiment_station_bulletins/581 @ WVU. It has been accepted for inclusion in West Virginia Agricultural and Forestry Experiment Station Bulletins by an authorized administrator of The Research Repository @WVU. For more information, please contact ian.harmon@mail.wvu.edu. 


\section{A Survey of the Nutritional Status of West Virginia Peach Orchards}

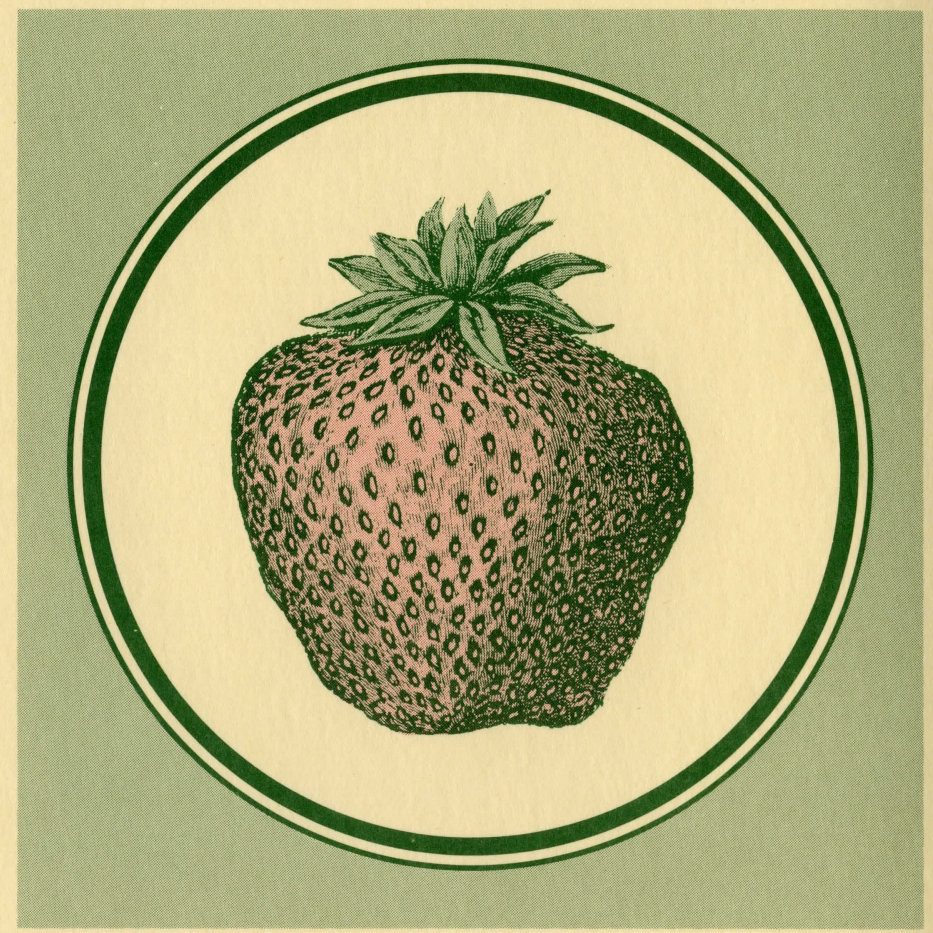

Bulletin 687

March 1984

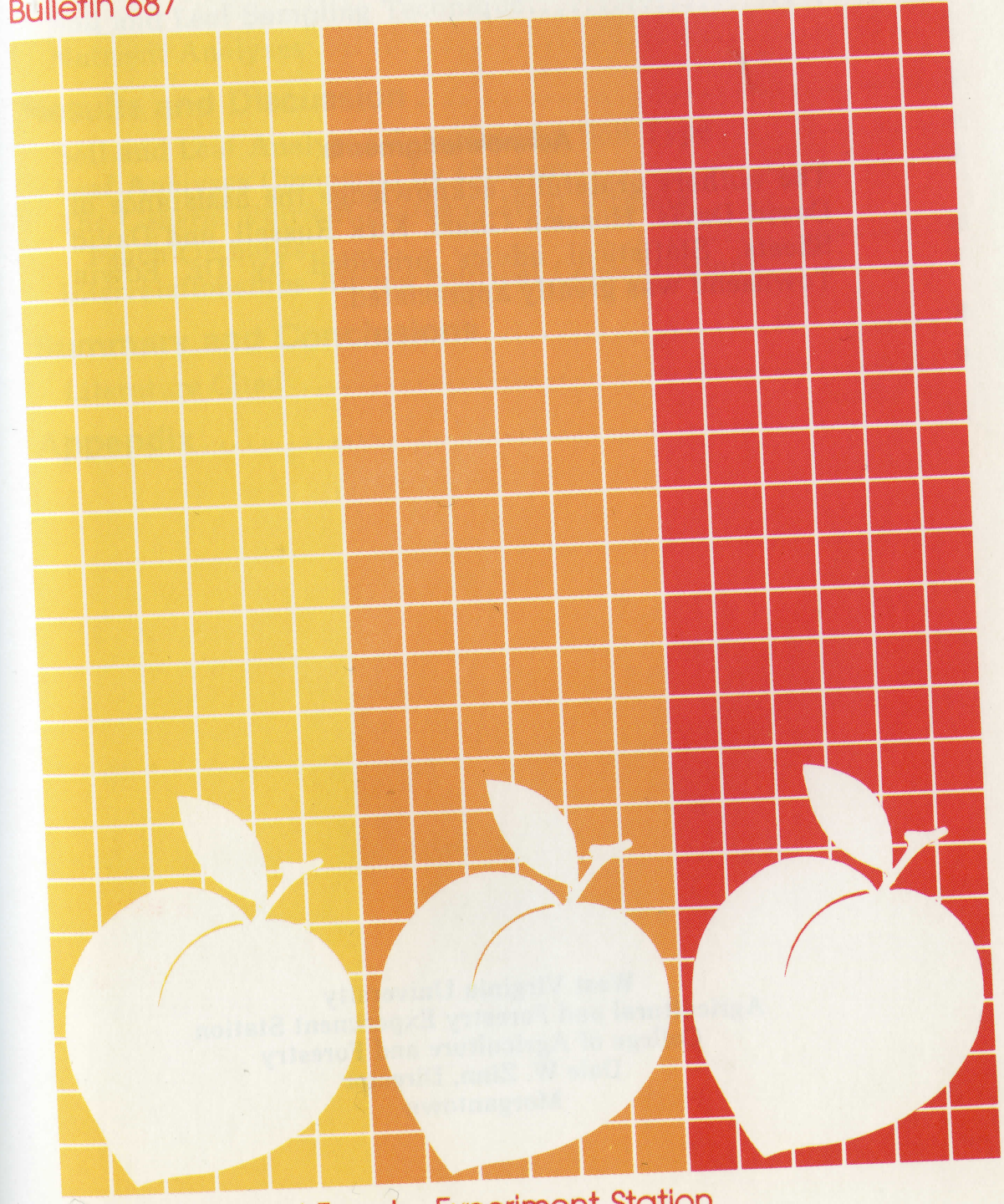

Agricultural and Forestry Experiment Station West Virginia University 


\section{Authors}

Tara L. Auxt is Extension Specialist in Horticulture and Assistant Horticulturist; Suman Singha is Associate Horticulturist; and Steve H. Blizzard is Associate Horticulturist.

\section{Acknowledgments}

The authors gratefully acknowledge the assistance of David Davis, Hussein Ghazi, Kirk Russell, and David Sheets. Statistical advice provided by Dr. Edwin Townsend was greatly appreciated.

West Virginia University

Agricultural and Forestry Experiment Station College of Agriculture and Forestry

Dale W. Zinn, Director

Morgantown

\section{Contents}

Introduction

Experimental Procedures

.

Regions, Soils and Cultivars Selected.................... 2

Soil and Leaf Sampling Technique.................... 2

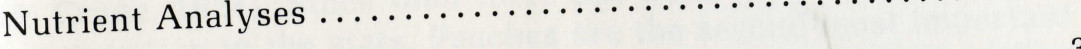

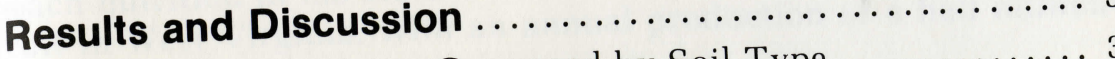

Soil and Leaf Analyses Compared by Soil Type...........

Leaf Analyses Compared by Cultivar ....................

The General Nutrient Status of West Virginia

Peach Orchards

Among Nutrient Concentrations ..........

Interrelationships Among Nutrient Concentrations .............

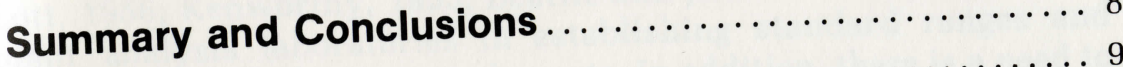

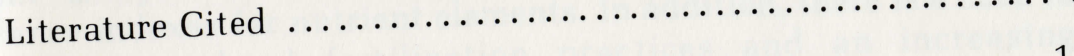

Appendix 


\title{
Survey of the Nutritional Status of West Virginia Peach Orchards
}

\author{
T. L. Auxt, S. Singha and S. H. Blizzard
}

\section{Introduction}

Research on peach fertilization in West Virginia in the late 1800 s was Research on peach for such research in the United States (Alderman, among the earliest of such research has been virtually no study of 1915; Crane, 1924). Since then there has been virtually important peach nutrition in the state. Peaches are the second most million fruit in bushels.

the nutritional status of West Virginia peach Information on the nutritional status of orchards is needed for the improvement of Welysis surveys conducted fertilizer recommendation services. Leaf analysis surve McClung and in other states (Smith, 1965; Boatwright et al., 1962; McClung and Lott, 1956; Kenworthy, 1953; Beattie and Judkins, 1952) have aided plant analysis laboratories in establishing standard ranges and balance indexes for nutrient elements. In addition, the is a neesing economize orchard fertilization practices and an incom economizes that nutrition may play a role in the complex problem of awareness that nutrition mards et al., 1976; Brittain and Miller, 1976). "peach tree decline" (Edwards et al., 197 for diagnosing an existing Leaf analysis can be a valuable tool for diagnosing deficiencies nutritional problem as well as for detecting approaching deficiencies and toxicities (Kenworthy, 1973).

With these objectives in mind, a leaf and soil analysis survey of

With these objectives in mious year, apple peach orchards was conducted in 1981. 1982). Knowledge gained orchards had been surveyed (Singha et al., 1982). Know for making from this survey will be used to improve the program for making fertilizer recommendations and to plan future nutrition studies.

\section{Experimental Procedures}

\section{Regions, Soils and Cultivars Selected}

The survey was conducted in the Eastern Panhandle of West Virginia, wat belt, ideally suited a region within the Cumberland-Shenty-five percent of the West for the production of tree fruits. Ninety-jefferson and Hampshire Virginia peach crop is grown in Berkeley, Jefferson and Hampshire
counties (W.Va. Dept. of Agr. Crop Reporting Service, 1982). Twenty- 
six orchards were sampled in these counties July 28-30, 1981. Locations of the orchards are shown in Figure 1.

Peach orchards are planted on two general types of soils-those formed from limestone and those formed from shale. Orchards in Jefferson and Berkeley counties are planted on deep limestone soils (usually more than nine feet of rooting capability) with a high waterholding capacity. The soils in Hampshire County are formed from shale and are shallow (less than four feet) and droughty by comparison (Browning and Sudds, 1941).

Cultivars sampled for the survey were Redhaven and Loring. Redhaven, an early-season peach, currently comprises 16 percent of the state's total peach production, and Loring, a mid-season cultivar, leads with 25 percent of the crop (W.Va. Dept. of Agr. Crop Reporting Service, 1982). Trees sampled were between 7-20 years of age and were either on Lovell or Halford rootstocks. With the exception of some signs of nitrogen deficiency, these trees did not exhibit symptoms of nutritional disorders.

\section{Soil and Leaf Sampling Technique}

Nineteen blocks of Redhaven and 26 blocks of Loring were sampled (Appendix Tables 1,2). Two replicate leaf and soil samples were gathered from each block, for a total of 90 leaf and 90 soil samples. Each leaf sample was a composite of ten leaves collected from the midregion of current season's shoot growth from each of ten trees. Shoots were randomly selected from all sides of each tree at a height of three to six feet. Soil samples were obtained from a depth of six to eight inches under the driplines of the same trees from which leaf samples were collected.

\section{Nutrient Analyses}

Leaf samples were washed, dried at $45^{\circ} \mathrm{C}$ in a forced air oven, and ground in a Wiley Mill equipped with a 20-mesh stainless steel sieve. The samples were analyzed for nitrogen $(\mathrm{N})$, phosphorus (P), potassium $(\mathrm{K})$, calcium $(\mathrm{Ca})$, magnesium $(\mathrm{Mg})$, iron $(\mathrm{Fe})$, manganese $(\mathrm{Mn})$, zinc $(\mathrm{Zn})$, copper $(\mathrm{Cu})$, and boron $(\mathrm{B})$ at the Department of Pomology, Cornell University, Ithaca, New York. Nitrogen was extracted with perchloric and sulfuric acids and determined with an ammonia specific electrode. The other nutrients were extracted by a dry ashing technique using nitric acid and analyzed with an inductively coupled argon plasma spectrograph

Soil samples were air-dried and sieved through a 20-mesh screen. P, $\mathrm{K}, \mathrm{Ca}, \mathrm{Mg}, \mathrm{pH}$, and lime requirement were determined at the West Virginia University Soil Testing Laboratory (Ghazi et al., 1978).

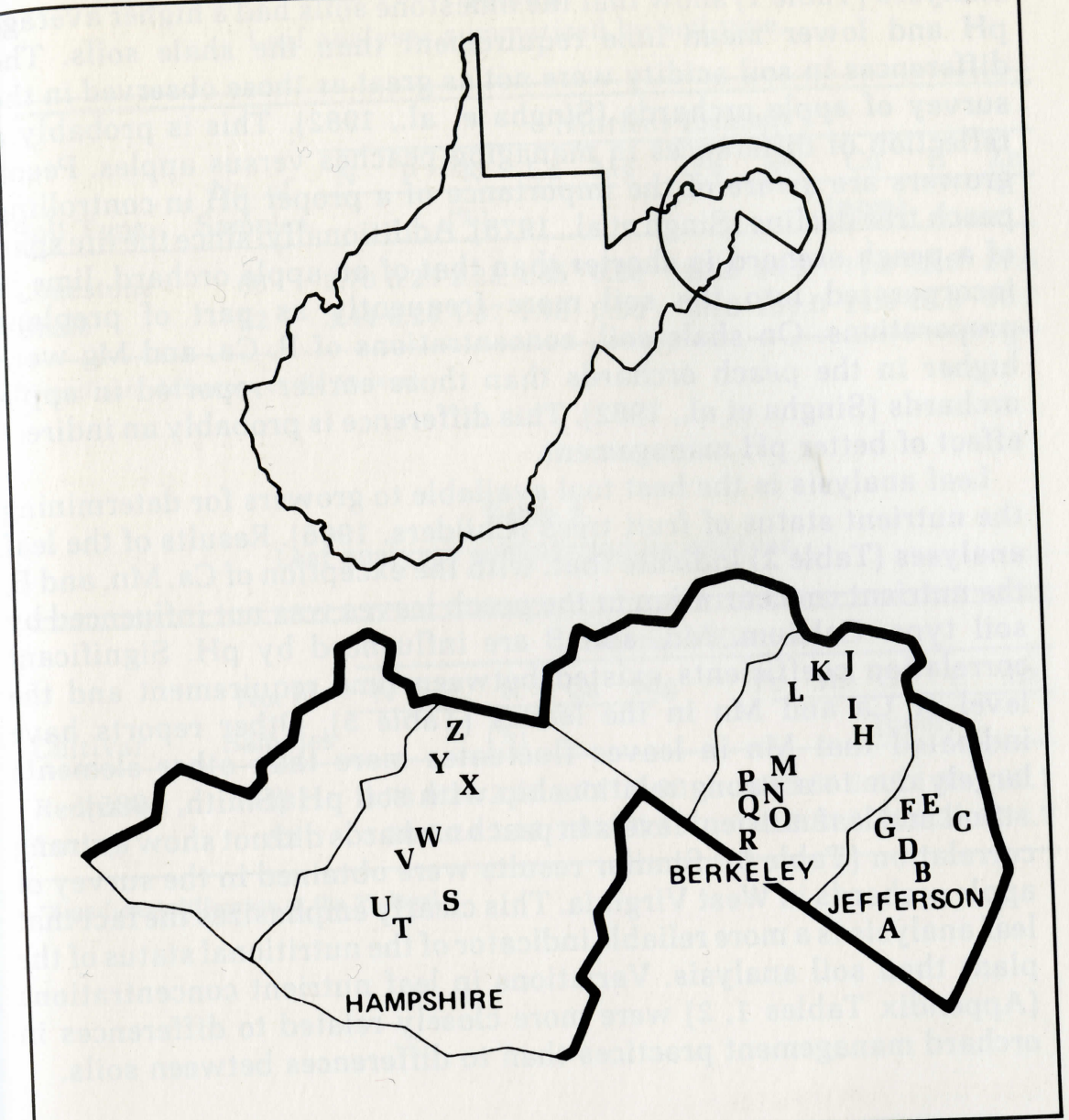

Figure 1. Locations of peach orchards where leaf and soil samples were collected.

\section{Results and Discussion}

\section{Soil and Leaf Analyses Compared by Soil Type}

Leaf analysis is a more reliable indicator of fertilizer needs of fruit (Singha et al., 1982; Kenworthy, 1973). Soil trees than soil analysis (Singha because it indicates the relative analysis is of value, however, because importantly, because it availability of nutrients to tree roots and more importar provides information on soil $\mathrm{pH}$ and lime requirement. Results of soil 
analyses (Table 1) show that the limestone soils had a higher average $\mathrm{pH}$ and lower mean lime requirement than the shale soils. The differences in soil acidity were not as great as those observed in the survey of apple orchards (Singha et al., 1982). This is probably a reflection of differences in managing peaches versus apples. Peach growers are aware of the importance of a proper $\mathrm{pH}$ in controlling peach tree decline (Singh et al., 1978). Additionally, since the life span of a peach orchard is shorter than that of an apple orchard, lime is incorporated into the soil more frequently as part of preplant preparations. On shale soil, concentrations of $\mathrm{P}, \mathrm{Ca}$, and $\mathrm{Mg}$ were higher in the peach orchards than those earlier reported in apple orchards (Singha et al., 1982). This difference is probably an indirect effect of better $\mathrm{pH}$ management.

Leaf analysis is the best tool available to growers for determining the nutrient status of fruit trees (Childers, 1966). Results of the leaf analyses (Table 2) indicate that, with the exception of $\mathrm{Ca}, \mathrm{Mn}$, and $\mathrm{B}$, the nutrient concentration in the peach leaves was not influenced by soil type. Calcium, Mn, and B are influenced by $\mathrm{pH}$. Significant correlation coefficients existed between lime requirement and the level of $\mathrm{Ca}$ and $\mathrm{Mn}$ in the leaves (Table 5). Other reports have indicated that $\mathrm{Mn}$ in leaves fluctuates more than other elements largely due to a strong relationship with soil $\mathrm{pH}$ (Smith, 1965).

Soil and leaf nutrient levels in peach orchards did not show a strong correlation (Table 5). Similar results were obtained in the survey of apple orchards in West Virginia. This clearly emphasizes the fact that leaf analysis is a more reliable indicator of the nutritional status of the plant than soil analysis. Variations in leaf nutrient concentrations (Appendix Tables 1,2 ) were more closely related to differences in orchard management practices than to differences between soils.

Table 1.

Soil analyses summarized by soil type.

\begin{tabular}{|c|c|c|c|c|c|c|c|}
\hline \multirow[b]{2}{*}{ Soil Type } & \multirow[b]{2}{*}{$\begin{array}{c}\text { No. of } \\
\text { Samples }\end{array}$} & \multirow[b]{2}{*}{$\mathrm{pH}$} & \multicolumn{5}{|c|}{ Nutrient Element (lbs./acre) } \\
\hline & & & $\begin{array}{c}L R^{* *} \\
\text { (tons/acre) }\end{array}$ & $\mathrm{P}$ & $\mathrm{K}$ & $\mathrm{Ca}$ & $\mathrm{Mg}$ \\
\hline Limestone & 68 & $6.4^{*}$ & $0.9^{*}$ & 64.3 & $151.6^{*}$ & 2073. & 178.5 \\
\hline Shale & 22 & 6.0 & 1.4 & 52.7 & 101.0 & 1705. & 168.6 \\
\hline
\end{tabular}

*Significant difference at the $5 \%$ level.

**Lime required to adjust $\mathrm{pH}$ to 6.6 .
Table 2.

Leaf analyses summarized by soil type.

\begin{tabular}{|c|c|c|c|c|c|c|c|c|c|c|c|}
\hline \multirow[b]{3}{*}{ Soil Type } & \multirow{3}{*}{$\begin{array}{c}\text { No. of } \\
\text { Samples }\end{array}$} & \multicolumn{10}{|c|}{ Nutrient Element } \\
\hline & & $\mathrm{N}$ & $\mathrm{P}$ & $\mathrm{K}$ & $\mathrm{Ca}$ & $\mathrm{Mg}$ & $\mathrm{Fe}$ & $\mathrm{Mn}$ & $\mathrm{Cu}$ & B & $\mathrm{Zn}$ \\
\hline & & \multicolumn{5}{|c|}{$(\%)$} & \multicolumn{5}{|c|}{$(\mathrm{ppm})$} \\
\hline Limestone & 68 & 3.70 & 0.25 & 2.25 & $1.85^{*}$ & 0.60 & 62.6 & $68.2^{*}$ & 11.83 & $33.9^{*}$ & 31.6 \\
\hline Shale & 22 & 3.44 & 0.23 & 1.87 & 1.48 & 0.50 & 60.0 & 101.0 & 11.5 & 26.0 & 39.7 \\
\hline
\end{tabular}

*Significant difference at the $5 \%$ level.

Table 3.

Leaf analyses summarized by cultivar.

\begin{tabular}{|c|c|c|c|c|c|c|c|c|c|}
\hline \multirow[b]{3}{*}{ Cultivar } & \multirow{3}{*}{$\begin{array}{c}\text { No. of } \\
\text { Samples } \\
\end{array}$} & \multicolumn{8}{|c|}{ Nutrient Element } \\
\hline & & $\mathrm{N}$ & $\mathrm{P}$ & $\mathrm{K}$ & $\mathrm{Ca}$ & $\mathrm{Mg}$ & $\mathrm{Fe} \quad \mathrm{Mn}$ & $\mathrm{Cu} \quad \mathrm{B}$ & $\mathrm{Zn}$ \\
\hline & & \multicolumn{5}{|c|}{$(\%)$} & \multicolumn{3}{|c|}{$(\mathrm{ppm})$} \\
\hline Redhaven & 38 & 3.73 & 0.26 & 2.19 & $1.71^{*}$ & 0.60 & 63.569 .21 & 12.132 .4 & 32.1 \\
\hline Loring & 52 & 3.56 & 0.24 & 2.13 & 1.80 & 0.55 & 60.881 .41 & 11.431 .6 & 34.7 \\
\hline
\end{tabular}

*Significant difference at the $5 \%$ level.

\section{Leaf Analyses Compared by Cultivar}

Differences in leaf nutrient concentrations among orchards were generally more significant than differences between cultivars (Table 3 , Appendix Tables 1,2 ). The variations among orchards could be 3 , Appendix Tables 1,2 . Th fertilizing and liming practices, spray explained by differences in ferthizing floors, and other cultural and programs, management
environmental factors.

environmental factors.

Foliar calcium levels in Loring were differences existed between the in Redhaven (Tultivars in the levels of other macro- or micronutrients. The twa cutions in Ca levels may reflect differences in the stage of fruit variations in between the early and mid-season varieties. 
Table 4.

Percentage of orchard blocks which were deficient or above standard range in various nutrients.

\begin{tabular}{lccc}
\hline \hline Nutrient & $\begin{array}{c}\text { Standard } \\
\text { Range* }^{*}\end{array}$ & $\begin{array}{c}\text { \% Below } \\
\text { Standard Range }\end{array}$ & $\begin{array}{c}\% \text { Above } \\
\text { Standard Range }\end{array}$ \\
\hline $\mathrm{N}$ & $3.00-4.00 \%$ & 7 & 13 \\
$\mathrm{P}$ & $0.15-0.45 \%$ & 0 & 0 \\
$\mathrm{~K}$ & $1.20-2.50 \%$ & 9 & 27 \\
$\mathrm{Ca}$ & $1.00-2.50 \%$ & 0 & 4 \\
$\mathrm{Mg}$ & $0.30-0.70 \%$ & 2 & 22 \\
$\mathrm{Fe}$ & $80-500 \mathrm{ppm}$ & $96^{* *}$ & 0 \\
$\mathrm{Mn}$ & $50-300 \mathrm{ppm}$ & $22^{* *}$ & 0 \\
$\mathrm{Cu}$ & $5-35 \mathrm{ppm}$ & 0 & 0 \\
$\mathrm{~B}$ & $25-50 \mathrm{ppm}$ & 7 & 0 \\
$\mathrm{Zn}$ & $20-50 \mathrm{ppm}$ & 0 & $4^{* * *}$ \\
\hline
\end{tabular}

*Oberly, G. H. 1981. (Personal communication). These levels should be used as a general guideline only. Minor variations can be expected. **Several samples had values below the standard range but not sufficiently low enough to warrant amelioration.

${ }^{* * *}$ Excessive levels were probably due to contamination by pesticides.

\section{The General Nutrient Status}

\section{of West Virginia Peach Orchards}

The results show no general shortage of macronutrients (Tables 3,4). Rather, there is an indication that a number of orchardists are overfertilizing with $\mathrm{N}, \mathrm{K}$, or Mg (Table 4). Shortages of $\mathrm{N}, \mathrm{K}$, or $\mathrm{Mg}$ were found in a few isolated blocks. Although not deficient, Ca levels in many orchards were at the lower end of the standard range. In most cases, low Ca was associated with a high lime requirement (Table 5). Micronutrient levels were generally adequate. Foliar levels of Fe and Mn were below the standard range in many orchards, but they were not low enough to warrant amelioration. The ranges that have been established for both of these nutrients are very wide (Kenworthy, 1953; Smith, 1965). Perhaps with further study, more exact ranges can be established for our orchard conditions.

Peach tree decline has been attributed to several interrelated factors, including cold injury, nutrition, nematodes, and various insects and diseases. Knowledge of soil-related factors is incomplete, but reports indicate that peach tree decline is less severe where levels of $\mathrm{Ca}$ are adequate, aluminum (Al) and $\mathrm{Mn}$ are not present in toxic quantities, and soil pH is maintained between 6.5 and 7.0 (Singh et al., 1978; Brittain and Miller, 1976; Edwards et al., 1976; Jones and Jones,
1974). Nitrogen has a secondary effect in that high levels are correlated with greater peach hardiness (Proebsting, 1957).

As reported in surveys in other states, N, P, K, Ca, Mg and Fe were higher in peach leaves that in apple leaves (Kenworthy, 1953; Boynton et al., 1950).

Table 5.

Degree of correlation among levels of various nutrients.

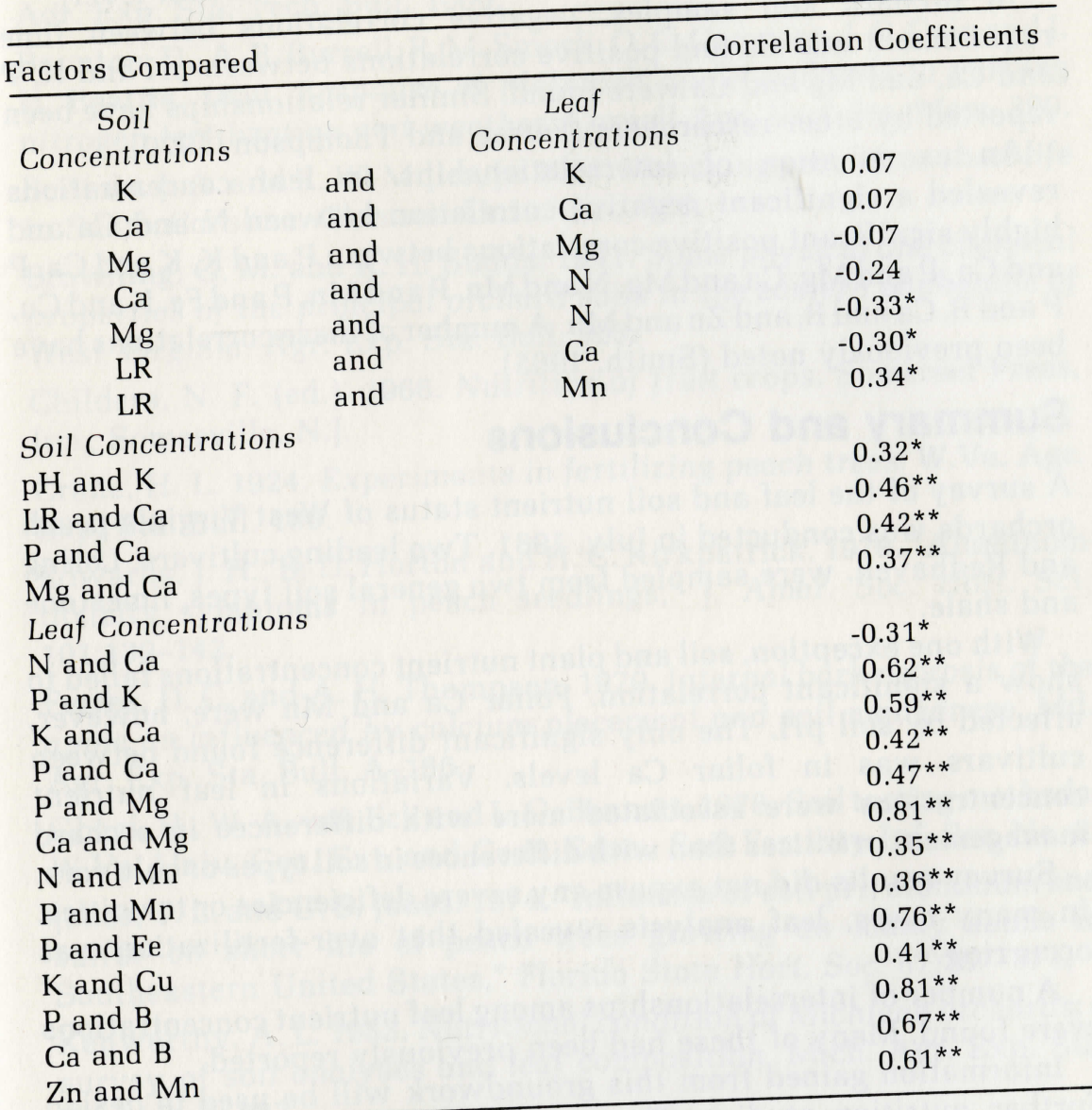

*Significant at the $5 \%$ level

**Significant at the $1 \%$ level.

\section{Interrelationships Among Nutrient Concentrations}

In determining fertilizer needs, interrelationships of nutrients should ingede the considered because excessive leve 
uptake of another nutrient. The degree of association between concentrations of various nutrient elements was determined by correlation coefficients (Table 5).

Levels of nutrients in the soil did not correlate with concentrations of the same nutrients present in the leaves. However, inverse relationships existed between soil $\mathrm{Mg}$ and leaf $\mathrm{N}$ and between lime requirement and leaf $\mathrm{Ca}$ ( 5 percent level), and a positive correlation existed between lime requirement and leaf Mn (5 percent level).

In orchard soil samples, negative correlations between lime requirement and $\mathrm{Ca}$ and positive correlations between $\mathrm{pH}$ and $\mathrm{K}, \mathrm{P}$ and $\mathrm{Ca}$, and $\mathrm{Mg}$ and $\mathrm{Ca}$ were found. Similar relationships have been reported by other researchers (Ferree and Thompson, 1970).

An examination of interrelationships in leaf concentrations revealed a significant negative correlation between $\mathrm{N}$ and $\mathrm{Ca}$ and highly significant positive correlations between $\mathrm{P}$ and $\mathrm{K}, \mathrm{K}$ and $\mathrm{Ca}, \mathrm{P}$ and $\mathrm{Ca}, \mathrm{P}$ and $\mathrm{Mg}, \mathrm{Ca}$ and $\mathrm{Mg}, \mathrm{N}$ and $\mathrm{Mn}, \mathrm{P}$ and $\mathrm{Mn}, \mathrm{P}$ and $\mathrm{Fe}, \mathrm{K}$ and $\mathrm{Cu}$ $\mathrm{P}$ and $\mathrm{B}, \mathrm{Ca}$ and $\mathrm{B}$, and $\mathrm{Zn}$ and $\mathrm{Mn}$. A number of these correlations have been previously noted (Smith, 1965).

\section{Summary and Conclusions}

A survey of the leaf and soil nutrient status of West Virginia peach orchards was conducted in July, 1981. Two leading cultivars, Loring and Redhaven, were sampled from two general soil types, limestone
and shale.

With one exception, soil and plant nutrient concentrations failed to show a significant correlation. Foliar Ca and Mn were, however, affected by soil $\mathrm{pH}$. The only significant difference found between cultivars was in foliar Ca levels. Variations in leaf nutrient concentrations were associated more with differences in orchard management practices than with differences in soil types or cultivars.

Survey results did not expose any severe deficiencies or toxicities. In many cases, leaf analysis revealed that over-fertilization was occurring.

A number of interrelationships among leaf nutrient concentrations were found. Many of these had been previously reported.

Information gained from this groundwork will be used to design further nutrition studies. The results of the survey indicate that further studies are warranted on acid orchard soils and on imbalances of $\mathrm{N}, \mathrm{K}$ and $\mathrm{Mg}$, especially as related to the problem of peach tree
decline.

\section{Literature Cited}

Alderman, W. H. 1915. The fertilization of peach orchards. W.Va. Agr. Exp. Sta. Bull. 150.

Beattie, J. M. and W. P. Judkins. 1952. Status of Ohio peach trees. Ohio Agr. Exp. Sta. Res. Circ. 17

. Skelton Boatwright, R. N., G. E. Stem south Carolina peach orchards. S. Car. Agr. Exp. Sta. Tech. Bull. 1006.

Agr. Exp. Stonton, D., A. B. Burrell, R. M. Smock, O. C. Compton, J. C. Cain and J. Besponse of McIntosh apple orchards to varying H. Beattie. 1950. Respons. Cornell Agr. Exp. Sta. Mem. 290. nitrogen fertilization and weathr. Managing peach tree short life Brittain, J. A. and R. W. Miller, Jr. Circ. 568.

in South Carolina. Clemson Univ. Circ. 568. Browning, G. M. and R. H. Sudds. 1941. Some physical and chemical properties of the principal orchard soils in

West Virginia. Agr. Exp. Sta. Bull. 303. Inc., Somerville, N.J.

Inc., Somerville, N.). Exp. Sta. Bull. 183.

Edwards, J. H., B. D. Horton and H. C. Kirkpatrick. 1976. "Aluminum toxicity symptoms in peach seedlings," J. Amer. Soc. Hort. Sci. 101:139-142.

Ferree, D. C. and A. H. Thompson. 1970. Internal bark necrosis of the apple as influenced by calcium placement and soil manganese. Md. Agr. Exp. Sta. Bull. A-166.

Ghazi, H., W. A. van Eck and L. G. Bennett. 1978. Soil testing methods. W.Va. Univ. Cen. Ext. and Cont. Educ., Soil Fertility Inf. Ser. No. 3. Jones, T. L. and U. S. Jones. 1974. "Influence of soil pH, aluminum and Jom trees growing on loamy sands sulfur on short life of peat." Florida State Hort. Soc. 87:367-371.

Kenworthy, A. L. 1953. Nutritional condition of Michigan orchards: a survey of soil analyses and leaf composition. Mich. Agr. Exp. Sta. Tech. Bull. 237.

Kenworthy, A. L. 1973. "Leaf analysis as an aid in fertilizing orchards," In Soil testing and plant analysis, L. M. Walsh and J. Beaton (eds.). Soil Sci. Soc. Amer., Madison, Wisc.

McClung, A. C. and W. L. Lott. 1956. "A survey of the nutrient Mclusition of leaf samples from North Carolina peach orchards," Soil Sci. Soc. Amer. Proc. 20:10-15 
Proebsting, E. L., Jr. 1957. "Effect of cover crop N level on Elberta peach production following 1957 freeze," Proc. Wash. State Hort. Assn. 53:89-90.

Singh, R. N., R. F. Keefer, R. E. Adams and A. R. Khawaja. 1978. "Preliminary report on toxic elements in relation to peach nutrition," The Mountaineer Grower 47:8-16.

Singha, S., T. L. Auxt, S. H. Blizzard and E. C. Townsend. 1982. A survey of the nutritional status of West Virginia apple orchards. W.Va. Agr. and For. Exp. Sta. Bull. 682.

Smith, C. B. 1965. A five-year nutritional survey of Pennsylvania apple, peach, and sour cherry orchards. Pa. Agr. Exp. Sta. Bull. 717. W.Va. Dept. of Agr. Crop Reporting Service. 1982. 1982 West Virginia Fruit Tree Survey. U.S. Dept. of Agr. Stat. Rep. Serv. 


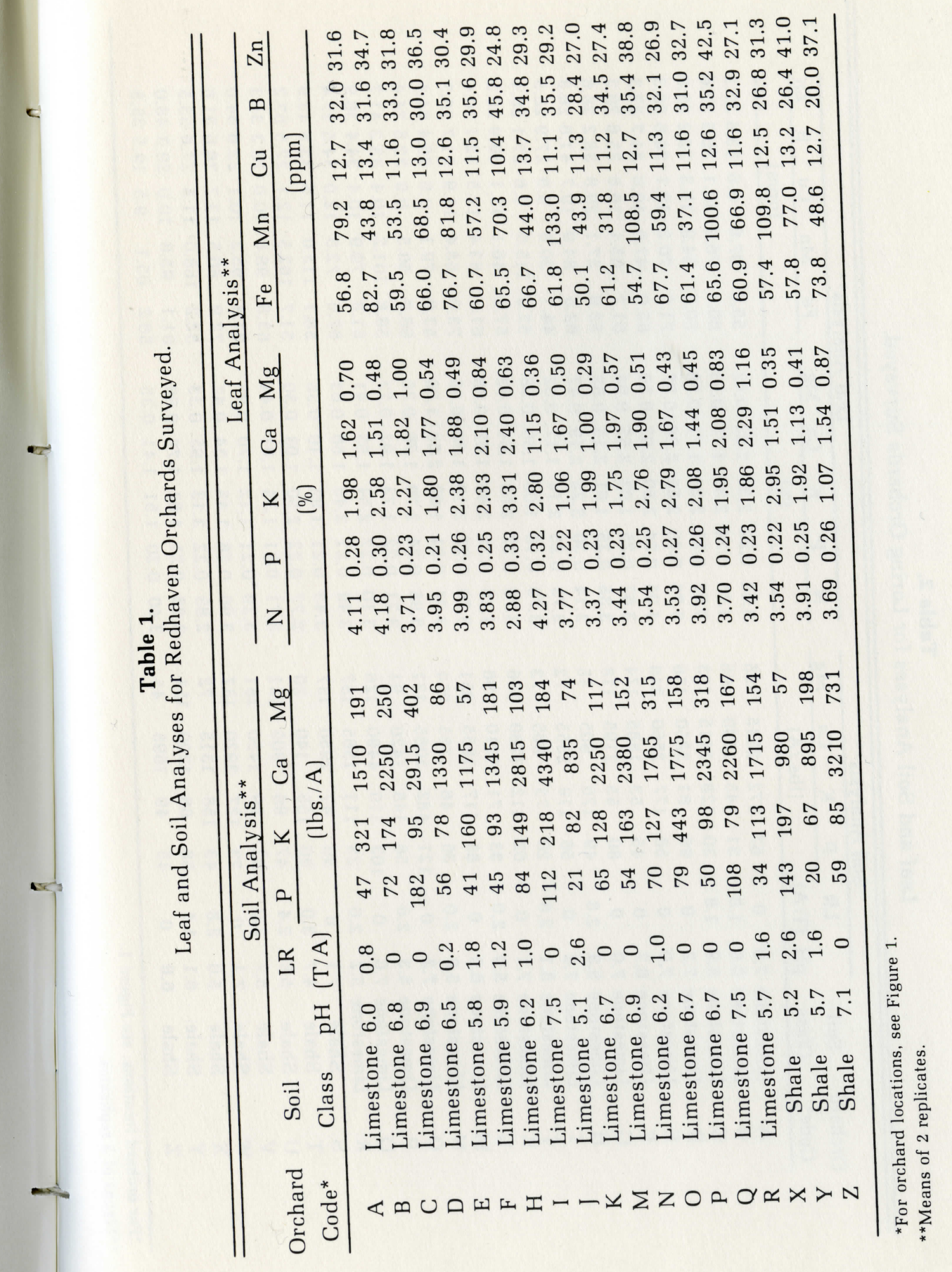




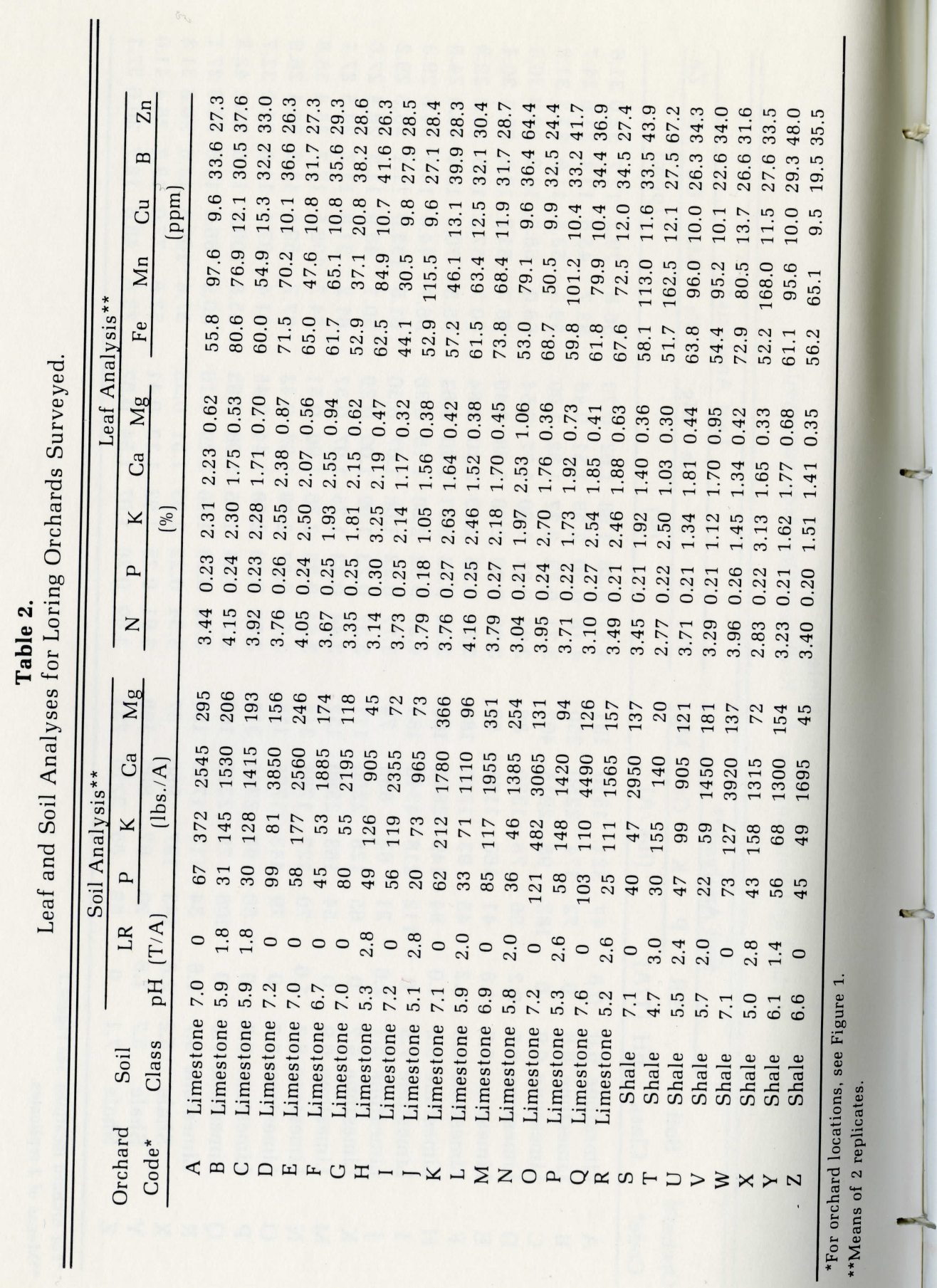

